Original Research

\title{
FORMULASI DAN UJI AKTIVITAS ANTIOKSIDAN DARI SEDIAAN MASKER PEEL-OFF EKSTRAK UMBI WORTEL VARIETAS CHANTENAY (Daucus carota L.)
}

\section{FORMULATION AND DETERMINATION THE ANTIOXIDANT ACTIVITY OF PEEL-OFF MASK OF THE EXTRACT OF CARROT TUBER CHANTENAY VARIETY (Daucus carota L.)}

\author{
Rabima $^{l^{*}}$, Sherli Desimah Pangaman ${ }^{2}$ \\ ${ }^{1,2}$ Fakultas Farmasi, Universitas 17 Agustus 1945, Jakarta Utara, Indonesia, 14350 \\ *E-mail: rabima86@gmail.com
}

Diterima: 04/09/2020

Direvisi: 10/09/2020

Disetujui: 01/10/2020

\begin{abstract}
Abstrak
Kulit merupakan bagian tubuh terluar, yang sering terkena paparan polusi. Penuaan kulit adalah proses biologis kompleks yang dimulai pada usia 20 tahun dan bersifat irreversible. Penuaan kulit dipengaruhi oleh kombinasi intrinsik dan ekstinsik, faktor tersebut mengakibatkan perubahan secara struktural dan fisiologis kumulatif dengan adanya perubahan progresif di setiap lapisan kulit, serta perubahan dalam penampilan kulit. Namun dapat dicegah dan diatasi dengan antioksidan untuk menangkal radikal bebas yang terjadi dikulit. Salah satu tumbuhan yang berpotensi memiliki aktivitas antioksidan yaitu tanaman umbi wortel dan jarang dilihat potensi aktivitas ekstraknya. Oleh karena itu, dalam penelitian ini dipilih umbi wortel sebagai bahan utama sebagai senyawa aktif sediaan masker gel peel-off untuk dilihat aktivitas antioksidannya. Dalam penelitian ini dilakukan uji aktivitas antioksidan ekstrak etanol 70\% umbi wortel varietas Chantenay (Daucus carota $\mathrm{L}$.) dengan menggunakan metode DPPH (1,1-diphenyl-2-picrylhydrazyl) untuk mengetahui nilai aktivitas antioksidan yang terdapat dalam ekstrak etabol $70 \%$ umbi wortel. Dan didapatkan hasil $\mathrm{IC}_{50}$ dari ekstrak etanol $70 \%$ umbi wortel varietas Chantenay sebesar 684,7165 yang dapat disimpulkan bahwa ekstrak etanol 70\% umbi wortel varietas Chantenay kurang aktif dan kurang berpotensi sebagai antioksidan, serta nilai $\mathrm{IC}_{50}$ Vitamin $\mathrm{C}$ yang sebagai pembanding dengan nilai 5,7963. Namun pada hasil uji stabilitas sediaan masker gel peel-off ekstrak umbi wortel pada semua konsentrasi didapatkan hasil memenuhi standar, serta formulasi yang memiliki stabilitas terbaik yaitu pada konsentrasi ekstrak 5\% dikarenakan hasil yang didapatkan konstan dan tidak melewati nilai standar stabilitas sediaan.
\end{abstract}

Kata kunci: aktivitas antioksidan; Daucus carota L.; ekstrak etanol $70 \%$ umbi wortel 


\begin{abstract}
Skin is the outermost part of the body, which is often exposed to pollution. Skin aging is a complex biological process that starts at age 20 and its irreversible. Skin aging is influenced by a combination of intrinstic and extrinsic, these factors cause in cumulative structural and physiological changes in presence of progressive changes in each layer of the skin, as well as changes in the appearance of the skin. But can be prevented and overcome by antioxidants to counteract free radicals that occur on the skin. One of the plants that has the potential to have antioxidant activity is carrot tuber plants and rarely seen extract activity. Therefore, in this study carrot tuber was chosen as the main ingredient as an active compound of peel-off gel mask for know the antioxidant activity. In this research, to find the antioxidant activity of extract of $70 \%$ ethanolic tuber carrot variety chantenay was tested using DPPH (1,1-diphenyl-2-picrylhydrazyl) to determine the value of antioxidant activity in $70 \%$ ethanolic extract of carrot tuber variety Chantenay (Daucus carota L.). And the result of $\mathrm{IC}_{50}$ from $70 \%$ ethanolic extract of carrot tuber variety Chantenay were 684.7165 which can be concluded that $70 \%$ ethanolic extract of carrot tuber variety Chantenay is less active and has no potential as an antioxidant, also $\mathrm{IC}_{50}$ value of Vitamin $\mathrm{C}$ as a comparison with result 5.7963. But on the result of the stability test of the peel-off gel mask in all concentrations was found that the result according to standards the best of gel peel-off mask, also the best concentration is at $5 \%$ concentration of extract carrot tuber variety chantenay, it cause the result is constant and not exceed the standard set.
\end{abstract}

Keywords: activity of antioxidant; Daucus carota L.; extract of 70\% ethanolic carrot tuber variety chantenay

\title{
PENDAHULUAN
}

Penuaan kulit yang bersifat irreversible dimulai pada usia 20 meskipun tanda-tanda tidak terlihat dalam waktu yang lama.[1] Penuaan kulit adalah proses biologis kompleks yang dipengaruhi oleh kombinasi endogen atau intrinsik (genetika, metabolisme seluler, hormon, dan proses metabolik) dan faktor penuaan ekstrinsik (faktor cahaya matahari kronis, polusi, radiasi pengion, kimiawi dan toksin). Faktor-faktor tersebut mengakibatkan perubahan secara struktural dan fisiologis kumulatif dengan adanya perubahan progresif di setiap lapisan kulit serta perubahan dalam penampilan kulit, terutama pada kulit yang terkena sinar matahari terus menerus. Berbeda dengan kulit tipis dan atrofi, berkerut kusut dan kering secara instrinsik (usia), kulit yang mengalami penuaan kulit karena factor eksternal biasanya ditunjukkan dengan epidermis menebal, kulit mengalami pigmentasi yang tidak merata, kerutan, kurangnya kelenturan kulit, kusam dan kasar.[4]

Dari semua factor tersebut, teori radikal bebas merupakan teori yang sering dikaitkan sebagai penyebab factor-faktor penuaan dini. Radikal UV merupakan pemicu yang sangat potensial dalam pembentukan radikal bebas ROS (Reaktive Oxygen Species) pada kulit [4]. Radikal bebas adalah suatu atom atau molekul yang sangat reaktif dengan electron yang tidak memiliki pasangan. [3]

Senyawa yang dapat menangkal radikal bebas adalah antioksidan. Sebagai bahan aktif, antioksidan berfungsi untuk melindungi kulit dari kerusakan akibat oksidasi sehingga dapat mencegah penuaan dini.[4] Antioksidan mempunyai berat molekul kecil, tetapi mampu menginaktivasi berkembangnya radikal. Antioksidan juga merupakan senyawa yang dapat menghambat reaksi oksidasi, dengan mengikat radikal bebas dan molekul yang sangat reaktif, akibatnya kerusakan sel akan dihambat. Salah satu antioksidan yang terdapat di alam adalah umbi wortel.

Di Indonesia memiliki iklim tropis dengan sinar matahari melimpah yang dapat menyebabkan resiko tinggi terhadap kerusakan kulit atau penuaan dini (premature aging). 
Selain itu semua orang terutama kaum wanita menginginkan agar penuaan dini tidak terjadi pada dirinya, banyak orang yang mulai timbulnya kerutan kulit wajah pada usia yang relatif lebih muda, bahkan pada usia awal 20-an. Adapun yang mengakibatkan timbulnya kerutan pada kulit wajah karena faktor baik internal maupun eksternal. Disamping itu adapun untuk mengurangi kerutan pada wajah dengan melakukan senam otot pada wajah. Mendambakan keindahan dan kecantikan kulit tidaklah mudah apalagi untuk negara yang beriklim tropis seperti di Indonesia ini, matahari ternyata merupakan ancaman yang berat bagi kecantikan kulit dan wajah. Untuk itu perlu pemakaian kosmetika antioksidan wajah yang cocok yang disesuaikan dengan jenis dan kondisi kulit wajah untuk mendapatkan wajah tampak awet muda dan mencegah penuaan dini.

\section{METODE}

\section{Sampel (Bahan) Penelitian}

Bahan kimia yang digunakan PVA, umbi wortel varietas Chantenay (Daucus carota L.), gliserin, metil paraben, tween 80, etanol 70\%, serbuk DPPH, vitamin C, aqua destillata, etanol $96 \%$.

\section{Prosedur kerja}

\section{Pembuatan Ekstrak Etanol 70\% Umbi Wortel (Daucus carota L.)}

Simplisia yang telah halus diekstraksi dengan etanol 70\%. Proses maserasi dilakukan selama 3x24 jam. Kemudian dilakukan penyaringan, filtrat dari maserasi dikumpulkan dan diuapkan dengan rotary evaporator (pada suhu $30-40^{\circ} \mathrm{C}$ ) hingga pekat dan bebas dari pelarut. Kemudian ekstrak dikentalkan dengan menggunakan waterbath sampai didapatkan ekstrak kental.

\section{Skrining Fitokimia} terpenoid.

Skrining fitokimia meliputi pemeriksaan alkaloid, flavonoid, saponin, tannin, dan

\section{Pemeriksaan Alkaloid}

Ekstrak ditambahkan pereaksi Mayer (Kalium Tetraiodomerkurat (II)), Wagner (Iodin dalam Kalium Iodida) dan Dragendroff (Bismuth nitrat dalam Kalium Iodida).

\section{Pemeriksaan Flavonoid}

Sebanyak $1 \mathrm{~mL}$ ekstrak kental ditambahkan $\mathrm{HCl}$ pekat dan logam $\mathrm{Mg}$.

\section{Pemeriksaan Saponin}

Ekstrak ditambahkan $10 \mathrm{~mL}$ air panas, lalu didinginkan, setelah dingin langsung dikocok kuat selama 10 detik, jika terbentuk buih yang stabil selama 10 menit setinggi $1-10 \mathrm{~cm}$ dan setelah ditambahkan 1 tetes $\mathrm{HCl} 2 \mathrm{~N}$ buihnya tidak hilang, maka menunjukkan adanya senyawa saponin.

\section{Pemeriksaan Tannin}

Ekstrak kental ditambahkan 3 tetes larutan $\mathrm{FeCl}_{3}$. 


\section{Pemeriksaan Terpenoid}

Ekstrak kental diuapkan sampai kering lalu ditambahkan $\mathrm{CH} 3 \mathrm{COOH}$ serta tambahkan $\mathrm{H} 2 \mathrm{SO} 4(\mathrm{P})$ melalui dinding tabung reaksi :

a. b.

hijau atau merah berarti positif steroid ditambahkan $\mathrm{H} 2 \mathrm{SO} 4(\mathrm{P})$ dan asam asetat anhidrat, jika berwarna ungu, merah, coklat berarti positif terpenoid. (Harborne, 1987)

\section{Uji Aktivitas Antioksidan Ekstrak Umbi Wortel varietas Chantenay (Daucus carota L.)} Pembuatan larutan DPPH (1,1-diphenyl-2-picrylhydrazyl) (0,125mM)

Pembuatan larutan DPPH dengan etanol proanalis dan di ukur absorbansinya dengan menggunakan elisa reader.

\section{Pembuatan Larutan Induk Vitamin C}

Pembuatan Vitamin C ditimbang sebanyak 10 mg kemudian dilarutkan dengan DMSO sebanyak $1 \mathrm{~mL}$ dalam labu ukur sehingga diperoleh konsentrasi larutan induk $10000 \mathrm{ppm}$.

\section{Pembuatan Larutan Pembanding Vitamin C}

Pengenceran larutan induk vitamin $\mathrm{C}$ dengan pipet volume.

\section{Pembuatan Larutan Induk Ekstrak Umbi Wortel}

Ekstrak umbi wortel ditimbang sebanyak $50 \mathrm{mg}$ kemudian dilarutkan dengan DMSO sebanyak $1 \mathrm{~mL}$ dalam labu ukur sehingga diperoleh konsentrasi larutan induk 50000 ppm

\section{Pembuatan Larutan Uji Ekstrak Umbi Wortel}

Larutan induk dipipet sebanyak $10 \mu \mathrm{l}, 5 \mu \mathrm{l}, 2,5 \mu \mathrm{l}, 1,25 \mu \mathrm{l}$ dan $0,625 \mu \mathrm{l}$ lalu dimasukkan dalam labu ukur $5 \mathrm{~mL}$, kemudian ditambahkan etanol sampai tanda batas dan diperoleh konsentrasi 1000 ppm, 500 ppm, 250 ppm, 125 ppm, dan 62,5 ppm.

\section{Pengukuran Aktivitas Antioksidan Larutan Vitamin C}

Pengukuran aktivitas antioksidan larutan dengan diukur absorbansinya menggunakan elisa reader.

\section{Uji Aktivitas Antioksidan Larutan Eksrtak Umbi Wortel}

Pengujian aktivitas larutan perkonsentrasi yang telah diencerkan dan diukur absorbansinya dengan elisa reader.

Perhitungan Besar Presentase Hambatan Antioksidan Terhadap Radikal Bebas

Menurut rumus untuk menghitung besarnya \% hambatan antioksidan terhadap radikal bebas sebagai berikut :

$(\%)$ hambatan $=\frac{(\text { Absorbansi blanko }- \text { Absorbansi sampel })}{\text { Absorbansi blanko }} \times 100 \%$

(Evelyn et al., 2014)

Formulasi Sediaan Masker Gel Peel-Off 
Pada penelitian ini rancangan formulasi sediaan masker gel peel-off dari ekstrak umbi wortel varietas chantenay (Daucus carota L.) adalah sebagai berikut :

Tabel 1. Formula Sediaan Masker Gel peel-off ekstrak umbi wortel

\begin{tabular}{|l|l|l|l|l|l|}
\hline \multirow{2}{*}{ Bahan } & \multicolumn{4}{|l|}{ Formulasi (gram) } & \multirow{2}{*}{ Fungsi } \\
\cline { 2 - 6 } & F0 & F1 & F2 & F3 & \\
\hline $\begin{array}{l}\text { Ekstrak Umbi } \\
\text { Wortel }\end{array}$ & - & 5 & 10 & 15 & Zat Aktif \\
\hline Vitamin C & 0,05 & - & - & - & Kontrol (+) \\
\hline PVA & 10 & 10 & 10 & 10 & Gelling Agent \\
\hline Gliserin & 10 & 10 & 10 & 10 & Humektan \\
\hline Metil Paraben & 0,2 & 0,2 & 0,2 & 0,2 & Pengawet \\
\hline Tween 80 & 1 & 1 & 1 & 1 & Surfaktan \\
\hline Etanol 96\% & 15 & 15 & 15 & 15 & Pelarut \\
\hline Aqua destillata & 100 & 100 & 100 & 100 & Pelarut \\
\hline
\end{tabular}

\section{Evaluasi Fisika \& Karakteristik Sediaan Masker Gel Peel-Off}

Evaluasi fisika sediaan meliputi pengujian organoleptik, homogenitas, viskositas dan rheology, pH, stabilitas dan cycling test serta evaluasi karakteristik meliputi pengujian waktu mengering, daya sebar, iritasi dan uji efektivitas antioksidan.

\section{HASIL DAN PEMBAHASAN}

\section{Pemeriksaan Karakteristik Ekstrak}

Pemeriksaan karakteristik meliputi pengujian organoleptis yang meliputi pemeriksaan bentuk, warna, dan bau.

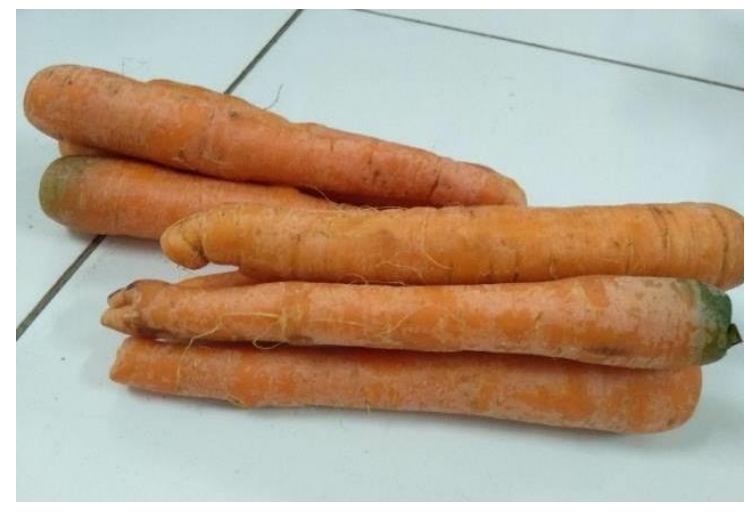

Gambar 1. Umbi Wortel 


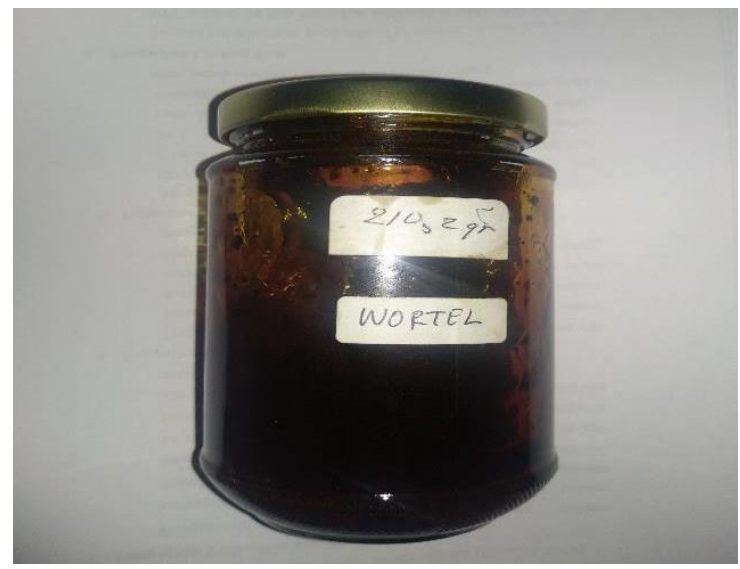

Gambar 2. Hasil Ekstraksi Umbi Wortel

Tabel 2 Hasil Uji Pemeriksaan Karakteristik Ekstrak

\begin{tabular}{|l|l|}
\hline Parameter Ekstrak & Hasil Parameter \\
\hline Organoleptis : & \\
\hline Bentuk & Ekstrak Kental \\
\hline Warna & Coklat Kehitaman \\
\hline Bau & Khas \\
\hline Rendemen & $8,314 \%$ \\
\hline Susut Pengeringan & $8,03 \%$ \\
\hline Kadar Air & $2,93 \%$ \\
\hline
\end{tabular}

Tabel 3. Hasil Perhitungan Rendemen

\begin{tabular}{|c|c|c|}
\hline Bobot Ekstrak $(\mathrm{g})$ & Bobot simplisia awal $(\mathrm{g})$ & Rendemen \\
\hline 122,01 & 1500 & $8,134 \%$ \\
\hline
\end{tabular}

Tabel 4. Hasil Uji Susut Pengeringan

\begin{tabular}{|l|l|l|l|l|}
\hline No. & $\mathrm{A}(\mathrm{g})$ & $\mathrm{B}(\mathrm{g})$ & $\mathrm{C}(\mathrm{g})$ & $\%$ \\
\hline 1. & 16,453 & 18,875 & 18,725 & $6,19 \%$ \\
\hline 2. & 16,451 & 18,652 & 18,555 & $4,40 \%$ \\
\hline 3. & 16,452 & 18,753 & 18,442 & $13,51 \%$ \\
\hline Rata- & 16,452 & 18,760 & 18,574 & $8,03 \%$ \\
\hline
\end{tabular}


Tabel 5. Hasil Uji Kadar Air

\begin{tabular}{|l|l|}
\hline No. & Kadar air \\
\hline 1. & 2,89 \\
\hline 2. & 3,29 \\
\hline 3. & 2,63 \\
\hline $\begin{array}{l}\text { Rata- } \\
\text { rata }\end{array}$ & 2,93 \\
\hline
\end{tabular}

\section{Skrining Fitokimia}

Hasil skrining fitokimia bertujuan untuk menunjukkan adanya beberapa kandungan kimia positif yang terdapat pada tanaman umbi wortel. Data identifikasi skrining fitokimia ekstrak umbi wortel varietas chantenay (Daucus carota L.) dapat dilihat pada tabel berikut :

Tabel 6. Hasil Skrining Fitokimia

\begin{tabular}{|c|c|c|c|c|}
\hline No. & $\begin{array}{c}\text { Kandungan } \\
\text { Kimia }\end{array}$ & Pereaksi & Hasil & Kesimpulan \\
\hline 1. & Alkaloid & Mayer & $+(\downarrow$ putih $)$ & Positif \\
\cline { 3 - 5 } & & Bouchardad & $+(\downarrow$ coklat $)$ & Positif \\
\cline { 3 - 5 } & Dragendorf & $+(\downarrow$ coklat $)$ & Positif \\
\hline 2. & Triterpenoid & $\begin{array}{c}\text { Asam Asetat Anhidrat } \\
+\mathrm{CHCl}_{3}+\mathrm{H}_{2} \mathrm{SO} 4(\mathrm{p})\end{array}$ & $+($ coklat $)$ & Positif \\
\hline 3. & Flavonoid & $\mathrm{Logam} \mathrm{Mg}^{\mathrm{HCHCl}(\mathrm{p})}$ & $+($ merah $)$ & Positif \\
\hline 4. & Tanin & $\mathrm{FeCl}_{3}$ & $-($ coklat $)$ & Negatif \\
\hline 5. & Saponin & Aqua Fervida & + (berbusa) & Positif \\
\hline
\end{tabular}




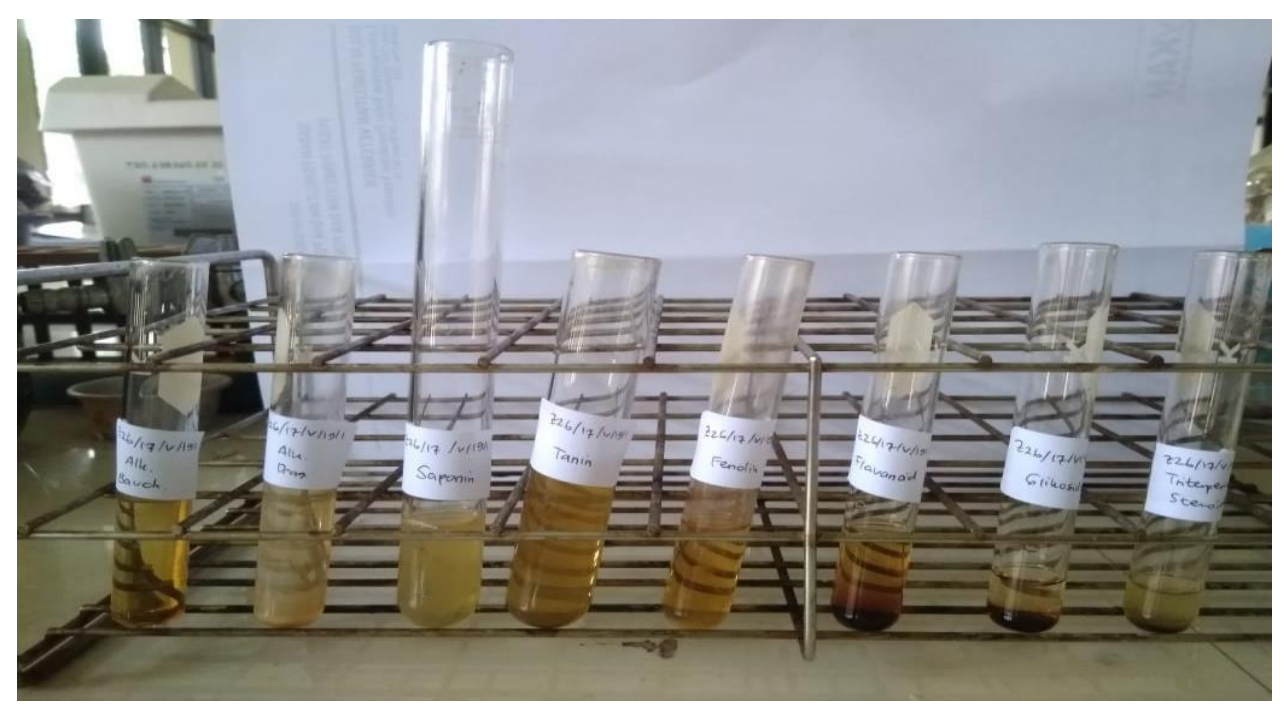

Gambar 3. Hasil Uji Skrining Fitokimia

\section{Uji Aktivitas Antioksidan Ekstrak Umbi Wortel varietas Chantenay (Daucus carota L.)}

Uji aktivitas antioksidan dilakukan dengan menggunakan metode DPPH (2,2-diphenyl1-picrylhydrazyl). Hasil yang diperoleh berupa nilai IC $_{50}$ yang akan menentukan efektivitas ekstrak umbi wortel dalam menangkal radikal bebas sebesar $50 \%$ namun dari hasil penelitian yang dilakukan hanya mencapai 684,7165 ppm sehingga kurang aktif namun masih berpotensi sebagai antioksidan. Data persen inhibisi atau hambatan antioksidan ekstrak umbi wortel dari vitamin $\mathrm{C}$ terhadap radikal bebas DPPH dapat dilihat pada tabel berikut :

Tabel 7. Hasil Uji Aktivitas Antioksidan Ekstrak

\begin{tabular}{|c|c|c|c|c|c|}
\hline \multirow{2}{*}{ Sampel } & \multirow{2}{*}{$\begin{array}{l}\text { Konsentrasi } \\
\quad(\mathrm{ppm})\end{array}$} & \multicolumn{2}{|c|}{$\%$ Inhibisi } & \multirow{2}{*}{$\mathrm{IC}_{50}$} & \multirow{2}{*}{ Persamaan Regresi Linier } \\
\hline & & $\mathrm{I}(\%)$ & II $(\%)$ & & \\
\hline $\begin{array}{l}\text { Ekstrak } \\
\text { Umbi } \\
\text { Wortel }\end{array}$ & $\begin{array}{c}62,5 \\
125 \\
250 \\
500 \\
1000\end{array}$ & $\begin{array}{l}10,345 \\
17,555 \\
27,272 \\
42,633 \\
65,204\end{array}$ & $\begin{array}{l}9,717 \\
17,868 \\
24,451 \\
43,887 \\
67,398\end{array}$ & 684,716 & $\begin{array}{l}\text { I. } y=0,0566 x+10,593 \\
\text { R2 }=0,9798 \\
\text { II. } y=0,0602 x+9,326 \\
\text { R2 }=0,9828\end{array}$ \\
\hline $\begin{array}{l}\text { Vitamin } \\
\mathrm{C}\end{array}$ & $\begin{array}{l}0,625 \\
1,25 \\
2,5 \\
5 \\
10\end{array}$ & $\begin{array}{l}2,251 \\
9,968 \\
22,185 \\
47,915 \\
84,566\end{array}$ & $\begin{array}{l}2,251 \\
9,325 \\
22,508 \\
46,623 \\
84,566\end{array}$ & 5,7963 & $\begin{array}{l}\text { I. } \\
\quad 8,7377 x-0,4823 \\
\text { R2 }=0,992 \\
\text { II. } y=8,7342 x-0,7905 \\
\quad R 2=0,994\end{array}$ \\
\hline
\end{tabular}


Tabel 8. Sifat Daya Antioksidan berdasarkan ppm [1]

\begin{tabular}{|c|c|}
\hline Daya antioksidan & Nilai ppm \\
\hline Sangat kuat & Kurang dari 50 ppm \\
\hline Kuat & $50-100 \mathrm{ppm}$ \\
\hline Sedang & $101-150 \mathrm{ppm}$ \\
\hline Lemah & $151-200 \mathrm{ppm}$ \\
\hline Kurang aktif namun berpotensi & $200-1000 \mathrm{ppm}$ \\
\hline
\end{tabular}

Berdasarkan tabel 8, didapatkan hasil bahwa $\mathrm{IC}_{50}$ dari ekstrak umbi wortel varietas Chantenay (Daucus carota L.) adalah 684,7165 ppm sehingga kurang aktif namun masih berpotensi sebagai antioksidan. Hasil tersebut lebih lemah dibandingkan Vitamin C yang memiliki nilai $\mathrm{IC}_{50}$ sebesar $5,796 \mathrm{ppm}$ dan termasuk antioksidan yang sangat kuat karena merupakan senyawa murni sedangkan ekstrak umbi wortel varietas Chantenay (Daucus carota L.) terdapat campuran berbagai senyawa.

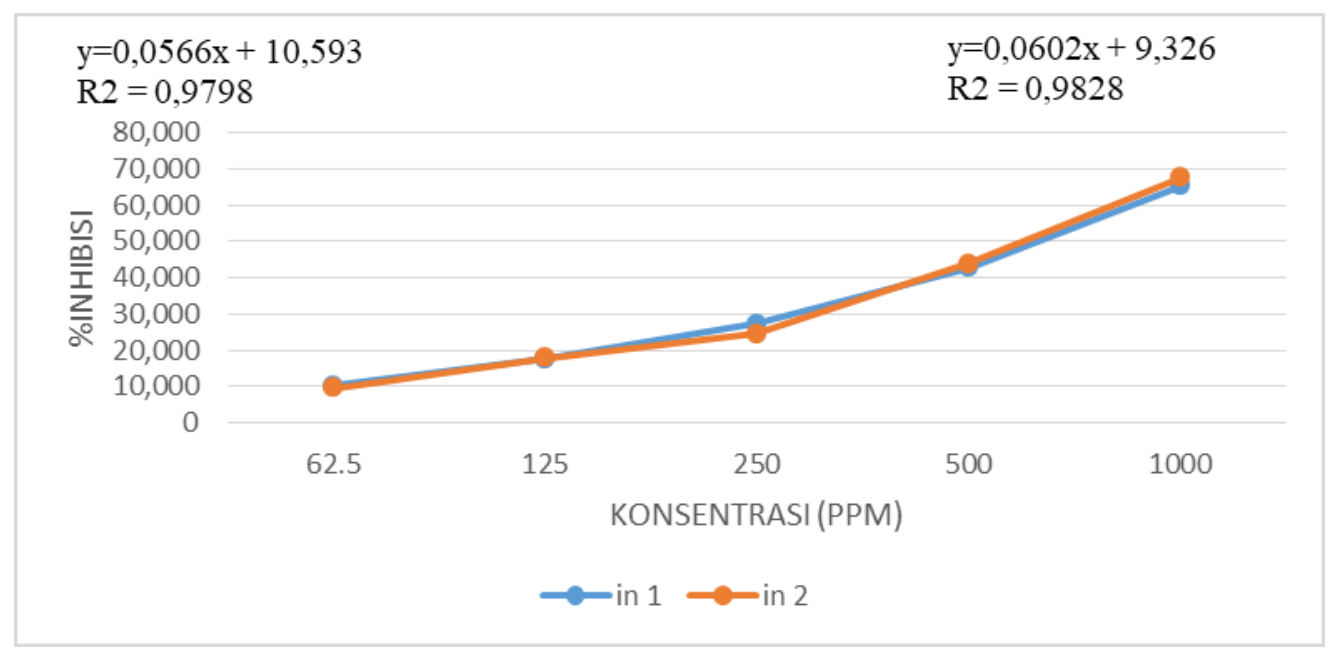

Gambar 4. Grafik Persentase Inhibisi Ekstrak Umbi Wortel 


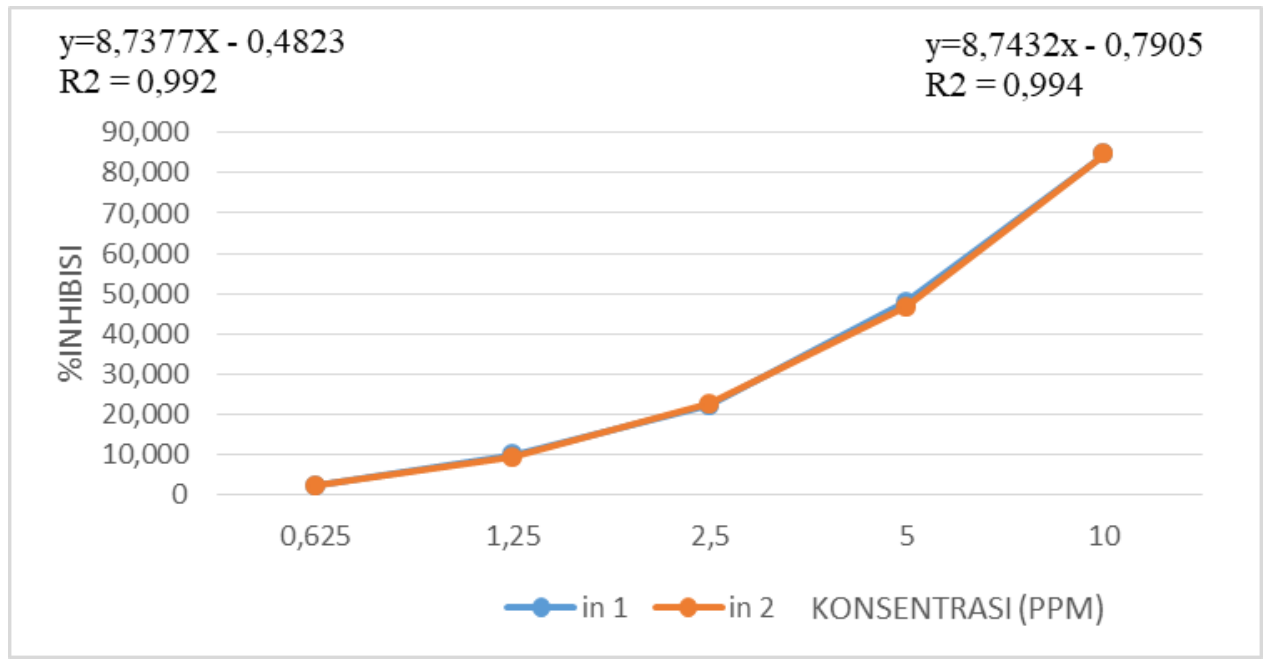

Gambar 5. Grafik Persentase Inhibisi Vitamin C

\section{Evaluasi Sediaan Masker Gel (Peel-Off) Ekstrak Umbi Wortel varietas chantenay (Daucus carota $\mathbf{L}$.)}

Evaluasi sediaan masker gel (peel-off) ekstrak umbi wortel varietas chantenay (Daucus carota L.) meliputi Uji Organoleptis, Uji Homogenitas, Uji Viskositas, Uji pH, Uji Kecepatan Mengering, Uji Iritasi, Uji Daya Sebar, dan Cycling Test. Hasil evaluasi sediaan masker gel (peel-off) per formulasinya di ringkas dalam tabel 9.

Tabel 9. Hasil pengamatan sediaan dalam ketiga formulasi selama 6 minggu

\begin{tabular}{|c|c|c|c|c|c|}
\hline \multirow{2}{*}{ Formula } & \multicolumn{4}{|c|}{ Pengamatan } \\
\cline { 2 - 6 } & Kondisi awal & \multicolumn{2}{|c|}{ Minggu ke-6 suhu $4^{0} \mathrm{C}$} & \multicolumn{2}{c|}{ Minggu ke-6 suhu $40^{\circ} \mathrm{C}$} \\
\cline { 2 - 6 } & $\begin{array}{c}\text { Warna dan } \\
\text { bau }\end{array}$ & $\begin{array}{c}\text { Warna dan } \\
\text { bau }\end{array}$ & $\begin{array}{c}\text { Pemisahan } \\
\text { fase }\end{array}$ & $\begin{array}{c}\text { Warna dan } \\
\text { bau }\end{array}$ & $\begin{array}{c}\text { Pemisahan } \\
\text { fase }\end{array}$ \\
\hline \multirow{3}{*}{$1(5 \%)$} & $\begin{array}{c}\text { Kuning } \\
\text { kecoklatan } \\
\text { dan berbau } \\
\text { khas wortel }\end{array}$ & $\begin{array}{c}\text { Kuning } \\
\text { kecoklatan } \\
\text { dan berbau } \\
\text { khas wortel }\end{array}$ & $\begin{array}{c}\text { Tidak } \\
\text { terjadi } \\
\text { pemisahan } \\
\text { fase }\end{array}$ & $\begin{array}{c}\text { Kuning } \\
\text { kecoklatan } \\
\text { dan berbau } \\
\text { khas wortel }\end{array}$ & $\begin{array}{c}\text { Tidak } \\
\text { terjadi } \\
\text { pemisahan } \\
\text { fase }\end{array}$ \\
\hline $2(10 \%)$ & $\begin{array}{c}\text { Coklat } \\
\text { kehitaman } \\
\text { dan berbau }\end{array}$ & $\begin{array}{c}\text { Coklat } \\
\text { kehitaman } \\
\text { dan berbau }\end{array}$ & $\begin{array}{c}\text { Tidak } \\
\text { terjadi } \\
\text { pemisahan }\end{array}$ & $\begin{array}{c}\text { Coklat } \\
\text { kehitaman } \\
\text { dan berbau }\end{array}$ & $\begin{array}{c}\text { Tidak } \\
\text { terjadi } \\
\text { pemisahan }\end{array}$ \\
\hline
\end{tabular}




\begin{tabular}{|c|c|c|c|c|c|}
\hline & khas wortel & khas wortel & fase & khas wortel & fase \\
\hline & $\begin{array}{c}\text { Coklat } \\
\text { kehitaman } \\
\text { dan berbau } \\
\text { khas wortel }\end{array}$ & $\begin{array}{c}\text { Coklat } \\
\text { kehitaman } \\
\text { dan berbau } \\
\text { khas wortel }\end{array}$ & $\begin{array}{c}\text { Tidak } \\
\text { terjadi } \\
\text { pemisahan } \\
\text { fase }\end{array}$ & $\begin{array}{c}\text { Coklat } \\
\text { kehitaman } \\
\text { dan berbau } \\
\text { khas wortel }\end{array}$ & $\begin{array}{c}\text { Tidak } \\
\text { terjadi } \\
\text { pemisahan } \\
\text { fase }\end{array}$ \\
& & & & \\
\hline
\end{tabular}

Gambar 6. Sediaan

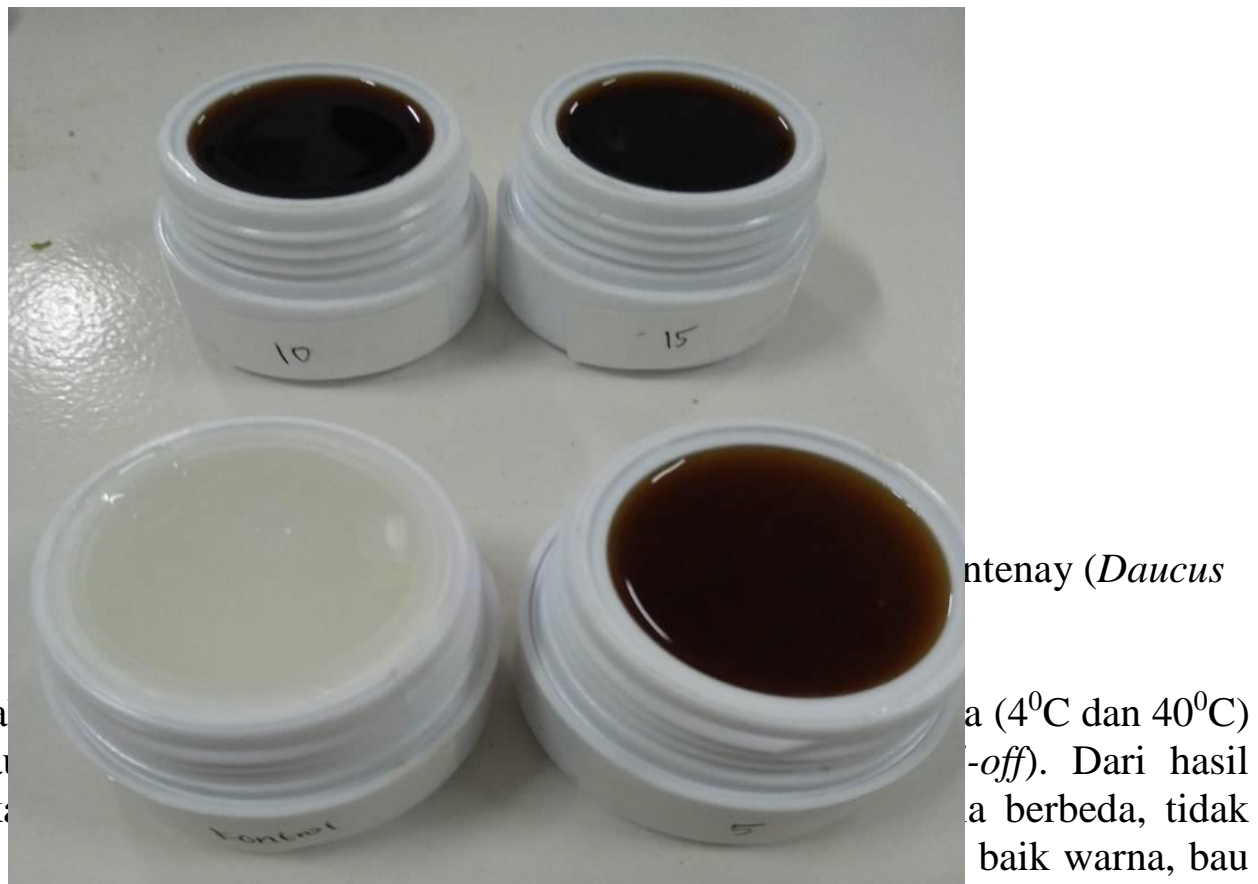

Cycling test dila dan diamati ada ata pengamatan didapatk menunjukkan adanya baik warna, bau dan tidak adanya pemisahan fase. Hal tersebut menunjukkan bahwa PVA merupakan gelling agent yang stabil dan mampu menyerap air dengan baik.

\section{Uji Efektivitas Antioksidan}

Uji efektivitas antioksidan dilakukan selama 4 minggu dengan menggunakan mencit jantan berusia 2 bulan, dan dilihat perubahan $\mathrm{pH}$ pada kulit punggung mencit yang terjadi. Hasil perubahan $\mathrm{pH}$ dapat dilihat pada tabel 10 . 
Tabel 10. Hasil Uji Efektivitas Antioksidan

\begin{tabular}{|c|c|c|c|c|c|}
\hline Formula & Mencit ke- & $\mathrm{pH}$ sebelum & $\mathrm{pH}$ sesudah & $\mathrm{pH}$ & Kesimpulan \\
\hline \multirow{4}{*}{$1(5 \%)$} & 1 & 5,55 & 6,20 & & Efektif \\
& 2 & 5,51 & 6,15 & & Efektif \\
& 3 & 5,87 & 6,22 & $4,5-6,5$ & Efektif \\
& 5 & 5,45 & 6,10 & & Efektif \\
& 5 & 5,60 & 6,25 & & Efektif \\
\hline \multirow{3}{*}{$2(10 \%)$} & 1 & 5,27 & 6,25 & & Efektif \\
& 2 & 5,45 & 6,15 & & Efektif \\
& 3 & 5,51 & 6,10 & $4,5-6,5$ & Efektif \\
& 5 & 5,61 & 6,05 & & Efektif \\
& 1 & 5,87 & 6,23 & & Efektif \\
\hline \multirow{3}{*}{$3(15 \%)$} & 2 & 5,55 & 6,14 & & Efektif \\
& 3 & 5,59 & 6,23 & & Efektif \\
& 4 & 5,87 & 6,24 & $4,5-6,5$ & Efektif \\
& 5 & 5,73 & 6,25 & & Efektif \\
\hline
\end{tabular}

Hasil pengamatan ini menunjukkan bahwa $\mathrm{pH}$ kulit dapat dipertahankan dengan adanya ekstrak umbi wortel varietas chantenay (Daucus carota L.) dalam masker gel peel-off yang digunakan. Hal ini dikarenakan ekstrak umbi wortel memiliki antioksidan yang dapat mencegah perusakan lipid interseluler dan komponen mantel asam ROS yang dihasilkan oleh sinar UV-B. Ketika perusakan lipid interseluler dapat dicegah, maka hidrasi kulit dapat terjaga dan kulit dapat bekerja dengan normal.

\section{KESIMPULAN}

Ekstrak etanol 70\% umbi wortel varietas Chantenay (Daucus carota L.) tidak memiliki aktivitas antioksidan berdasarkan hasil dari uji antioksidan dengan metode DPPH yang didapatkan hasil 684,716 ppm, sedangkan nilai $\mathrm{IC}_{50}$ vitamin $\mathrm{C}$ yaitu 5,7963 yang disimpulkan bahwa vitamin $\mathrm{C}$ memiliki aktivitas antioksidan yang sangat kuat. Formulasi masker peel-off ekstrak umbi wortel varietas Chantenay (Daucus carota L.) terbaik dari hasil uji evaluasi yaitu pada konsentrasi 5\%. Dikarenakan pada konsentrasi tersebut tidak terlalu pekat dan tidak mempengaruhi kekentalan pada sediaan masker gel peel-off.

\section{DAFTAR RUJUKAN}

1. Hitoshi Masaki. Role of antioxidants in the skin: Anti-aging effects, Nikkol Group Cosmos Technical Center Co., Ltd., Hasune, Itabashi-Ku, Tokyo 174-0046, Japan. 2001. 3-24-3.

2. Jaelani. Ensiklopedia Kosmetika Nabati. Jakarta: Pustaka Populer Obor. 2009.

3. Lestari, P.M., Sutyasningsih, R.B. and Ruhimat. The Influence of Increase Concentration Polivinil Alcohol (PVA) As a Gelling Agent On Physical Properties of The Peel-Off Gel Of Pineapple Juice (Ananas comosus L.) Asian Societies of Cosmetic Scientists Conference. 
2013.

4. Mackiewicz, Z., Rimkevicius, A. Skin Aging. Institute of Experimental and Clinical Medicine at Vilnius University; 2008.

5. Rowe, Raymond C, P. J. Sheskey, S. C. Owen. Handbook of Pharmaceutical Excipients, 5th ed. London: The Pharmaceutical Press. 2006.

6. Ruta Ganceviciene, Aikaterini I. Liakou, Athanasios Theodoridis, Evgenia Makrantonaki \& Christos C. Zouboulis. Skin anti-aging strategies, Dermato-Endocrinology,4:3. 2012. 308319.

7. Sweetman, S.C. Martindale The Complete Drug Reference (36th ed). London: Pharmaceutical Press. 2009.

8. Voigt, R. Buku Pelajaran Teknologi Farmasi Terjemahan. Yogyakarta: UGM. 1995.

9. Wade, A. dan Waller, P. J., Handbook of Pharmaceutical Excipients, Second Edition, The Pharmaceutical Press, London. 1994.

10. Winarsi, H. Antioksidan Alami \& Radikal Bebas. Kanisius. Yogyakarta. 2007. 